\title{
Genesis of Au-containing magmatic deposits of the non-ferrous metals in island-arc structures (Lesser Caucasus and East Pontids), data on inclusions and isotopic investigations
}

\author{
${ }^{1}$ Shahla Abdullayeva, ${ }^{2}$ Vasif Baba-zadeh, ${ }^{3}$ Sergo Kekeliya, ${ }^{4}$ Nazim Imamverdiyev, \\ ${ }^{5}$ Maren Kekeliya, ${ }^{6}$ Alexander Romanko \\ ${ }^{1}$ Baku State University, Azerbaijan, Associate professor, Ph.D \\ ${ }^{2}$ Baku State University, Azerbaijan, Professor, $\mathrm{Dr}$ \\ ${ }^{3}$ Geology Institute of Georgia, Professor, Dr \\ ${ }^{4}$ Baku State University, Azerbaijan, Professor, Dr \\ ${ }^{5}$ Geology Institute of Georgia, Associate professor, Ph.D \\ ${ }^{6}$ Geological Institute, Academy of Sciences, Moscow, Russian Federation, Ph.D
}

\begin{abstract}
*Corresponding Author: Alexander Romanko, Geological Institute, Academy of Sciences, Moscow, Russian Federation, email; a-romanko@ya.ru
\end{abstract}

\begin{abstract}
The geological settings of deposits exploration in Turkey, Azerbaijan, Armenia and Georgia have been determined in the article. Most of them can be related to the Kuroko type and they are differed by ore accumulation nature: the copper-zinc deposits formed apparently in the conditions of the deep sea basin are known in Turkey but to the east - we have only epigenetic deposits examples. Moreover, Madneuli deposit is developed in Bolnisi region. It is an example of polyformational deposit and therefore is unique. The barite deposits, barite-polymetallic veins, gold-bearing secondary quartzites and large-scale stock works of copper ores are concentrated in a confined space (known as biclinal structure on large volcano slope).

Gadabey and Alaverdi ore districts are of interest because there are copper, copper-zinc and barite-sulphide ores in the Jurassic volcanic depressions but copper-porphyry deposits - Garadag and Tekhut are known in upstanding wedge-shaped blocks limiting volcanic depressions. All deposits of Gadabey and Alaverdi ore districts including copper-porphyry are commercially important.
\end{abstract}

The solutions from which the sulphides deposited were similar to seawater according to salinity and were weakly acidic; copper-containing sulphides were formed at maximum 410-390 ${ }^{\circ} \mathrm{C}$ temperatures but baritesulphide ones - at $\sim 280^{\circ} \mathrm{C}$. In all probability the fluid pressure didn't exceed 200 bar in the epigenetic deposits. The stable accumulation of hydrothermal-sedimentary deposits occurred at the bottom of the sea which depth reached 2-3 $\mathrm{km}$.

Apparently, the fluid boiling didn't occur and mineral zonation in deposits being similar to modern "ore hills" can be explained by redistribution of the ore-forming components as a result of "hills" destruction, their diffusion from the lower levels up to the upper ones in the process of ores "washout" by ore-bearing fluids.

Keywords: Pontic-Lesser Caucasus arcs or paleoarcs, gold (Au)-bearing volcanogenic massive sulfides $(V M S)$ deposits and porphyry copper (PCD) deposits, inclusions, sulfur and oxygen isotopic ratio, metallogeny, magmatism

\section{INTRODUCTION}

The paleoisland-arc or simply - island arc fragments and back-arc and intra-arc marine paleobasins adjacent to its have been preserved in the central part of the Alpine-Himalayan mountain-fold belt (they displayed in black font in Fig. 1). Commercial significant Alpine gold-containing volcanogenic deposits of the non-ferrous metals have concentrated within these structures.

The most representative gold-containing volcanogenic deposits are known in the strata composing 
fragments of the Pontic-South Caucasus paleoarc that functioned actively during Mesozoic time in the South Caucasus countries and Turkey. At this time oceanic crust subducted under arc which was marginal part of the Eurasian continent (Dixon, Pereira, 1974; Zonenshayn, Kovalev, 1974; Güner, 1980, Monin, Zonenshayn, 1985; Okay, Şahintürk, 1997; Adamia et al., 2011).

The individual arc segments were differed by their geodynamic development wherefore the heterogeneous volcanogenic deposits occurred. Apart from epigenetic deposits there are also known hydrothermal-sedimentary deposits in the west, within Pontids (Turkey). Chaeli deposit (Madenkoy) can be an example of the last ones (Altun, 1977; Akçay, Arar, 1999).

The above-mentioned geological events are accompanied by: 1) micro plates divergence (TriassicEarly Bajocian) and mantle diapirism activation; 2) convergence (Late Bajocian-Early period of Late Cretaceous) with typical island arc volcanism both in the upstanding blocks (islands) and in marine depressions located on South Caucasian-Pontic microplate (Zonenshayn, Kovalev, 1974; Monin, Zonenshayn, 1985; Yaroshevich, 1985; Ustaömer, Robertson, 1993; Yilmaz et al., 1997; Yilmaz et al., 2000). During microplates convergence the epigenetic gold-containing volcanogenic deposits of copper and barite-polymetals (Gadabey Bitti-Bulag, Novo-Gorelovka, Gyulyatag, Janyatag, Kyapaz, Alaverdi, Shamlug, Kafan, Akhtala) were occurred firstly (Jurassic period) but copper-porphyry ones as Garadag, Damirli, Tekhut - in Early Cretaceous (Baba-zadeh, 1990; Baba-zadeh, et al., 2012; Babazadeh, Abdullayeva, 2012). All of them were detected in Azerbaijan and Armenia. The epigenetic copper, gold, barite-polymetallic deposits such as Bolnisi (Georgia) (Kekeliya et al., 1991; Kekeliya et al., 1993), Dagkesaman (Azerbaijan) (Baba-zadeh, Abdullayeva, 2012) and etc. formed at early collision stage in activated back-arc volcanic depressions. Volcanogenic-sedimentary copper-zinc ores (Chaeli and others, Turkey) were accumulated in intra-arc sea basins (Late Cretaceous), in the west, in the Eastern Pontids and there were formed large-scale epigenetic ores - Murgul deposit and etc. (Dixon, Pereira, 1974; Altun, 1977; Güner, 1980; Lethch Graig, 1981; Çakir, 1995; Akçay, Arar, 1999).

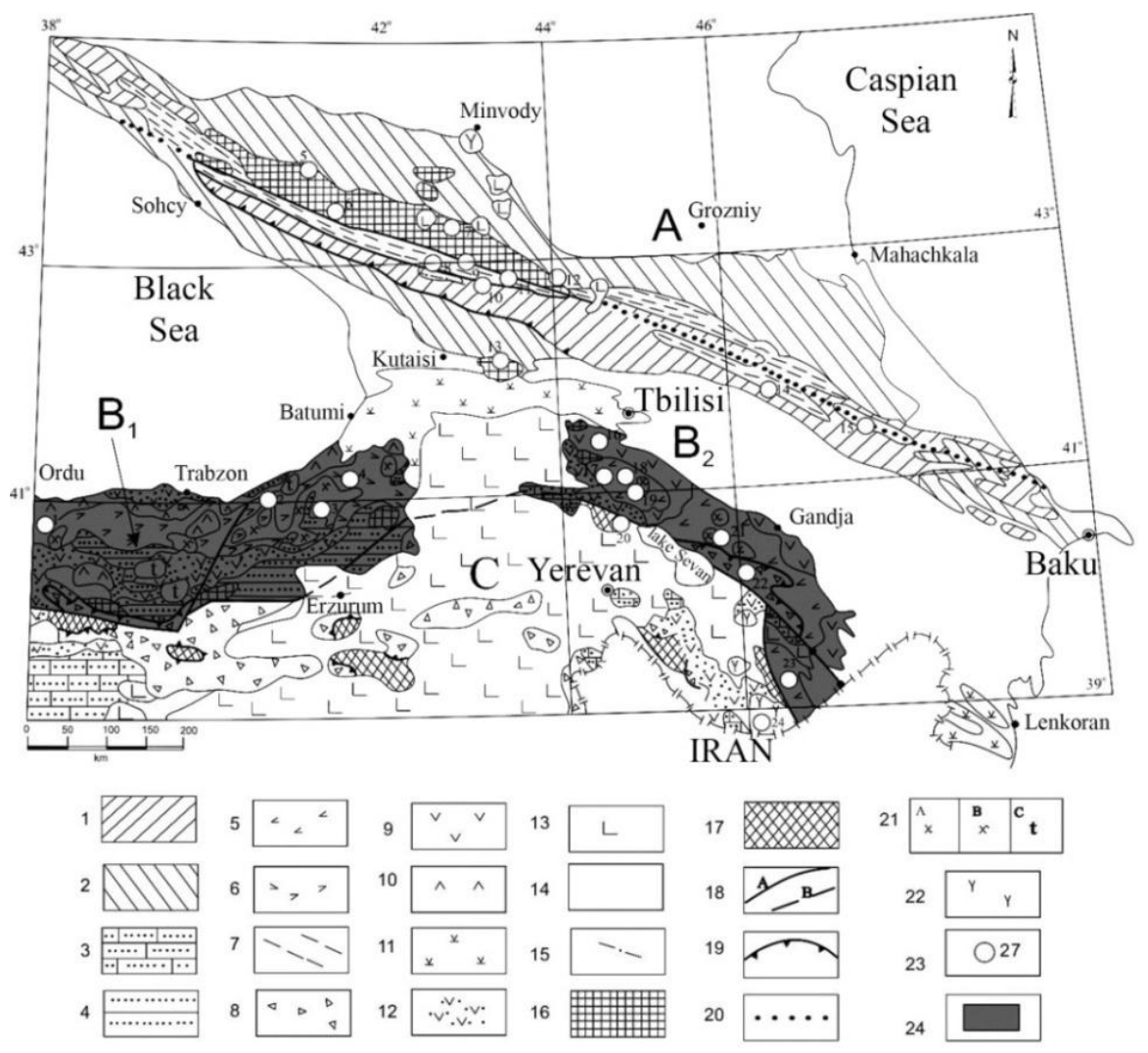

Fig.1. Main ore deposits distribution within Eastern Turkey and the Caucasus.

1 - Slope and uplift of the South Caucasus microcontinent (Jurassic-Early Cretaceous, the Greater Caucasus); 2 - shelf zone of the Scythian and South-Caucasus microcontinents (Jurassic - Paleogene, the Greater Caucasus; 3 - shelf zone of Anatolian and Daralagez microcontinents (Cretaceous Paleogene), 4 - shelf zone of Pontian microcontinent (Early Jurassic, Eastern Pontids); 5 - Lesser 
Caucasus ensialic island arc (Bajocian-Early Cretaceous); 6 - Pontian ensialic island arc (Cretaceous); 7 - Deep water basins of the marginal paleosea (Early-Middle Jurassic); 8 - Oceanic zones in allochtonous occurrence; 9 - Lesser Caucasus back-arc volcanic depression (Late Cretaceous); 10 Pontian back-arc volcanic depression (Late Cretaceous); 11 - intraplate riftogenic volcanic structures (Eocene-Oligocene, Lesser Caucasus); 12 - Eocene volcanic depressions superimposed on precollision structures (Pontids, Lesser Caucasus, Anatolids) 13 - Young volcanic plateau (OligoceneQuaternary); 14 - Orogenic troughs (Oligocene-Quaternary); 15 - Terrigenous-volcanic rocks (Dizi series, Devonian - Triassic) intruded by Middle Jurassic granitoids; 16- Pre-Alpine basement of Scythian and South Caucasus microplates (Pre-Cambrian-Paleozoic); 17 - Pre-Alpine basement of Anatolid and Daralageza (North Iran microplate, Pre-Cambrian-Paleozoic); 18 - tectonic wedges separating the main geoblocks (overfaults and faults, A - determined, B - prospective); 19 - thrusts; 20 - prospective borderline between the Scythian and the South Caucasus microplates (overthrusted); 21 - granitoids (a - Early Cretaceous, b - Late Cretaceous, c - Eocene - Oligocene); 22 - monzonites, syenites (Oligocene - Miocene); 23 - commercial minerals deposits; 24- paleoisland arc fragments.

The most important ore deposits of the Eastern Pontids and the Caucasus: 1- Ashikoy $(\mathrm{Cu}), 2$ Lakhanos (Cu, Zn, Pb), 3 - Chaeli-Madenkoy (Cu, Zn), 4 - Murgul (Cu, Zn), 5-Urup (Cu), 6 - KtiTeberda (W), 7 - Tyrny-Auz (W), 8 - Lukhra (Au), 9 - Tsana (As, Au), 10 - Lukhumi (As), 11 Zopkhito (Au, Sb), 12 - Sadon (Pb, Zn), 13 - Chiatura (Mn), 14 Filizchay (Zn, Pb, Cu), 15 - KizilDere $(\mathrm{Cu}), 16$ - Madneuli $(\mathrm{Cu}, \mathrm{Au}, \mathrm{Zn}, \mathrm{Pb}), 17$ - Alaverdi $(\mathrm{Cu}), 18$ - Shamlug $(\mathrm{Cu}), 19$ - Tekhut $(\mathrm{Cu})$, 20 - Megradzor $(\mathrm{Au}), 21$ - Dashkesan (Fe, $\mathrm{Co}), 22$ - Zod ( $\mathrm{Au}), 23-\mathrm{Kafan}(\mathrm{Cu}), 24-\mathrm{Kajaran}(\mathrm{Cu}, \mathrm{Mo})$, 25 - Chovdar $(\mathrm{Au}), 26$ - Gadabey $(\mathrm{Cu}), 27$ - Garadag $(\mathrm{Cu})$. Microplates: Eurasian paleocontinent: AScythian, B-Pontian-South Caucasus ( $\mathrm{B}_{1}$-East Pontids, $\mathrm{B}_{2}$-South Caucasus); Afro-Arabian paleocontinent: $\mathrm{C}$ - North Iran.

\section{EASTERn PonTids (TURKey) AND Their Ore CONTENT}

In the Eastern Pontids volcanogenic deposits were formed in volcanic depressions representing the intra-arc sea basins' parts in Cenomanian-Campanian but plutonogenic copper and molybdenum porphyry - in connection with granitoids formation in the upstanding blocks in relation to depressions. Ashikoy, Lakhanos, Kutlular, Chaeli, Murgul, Cherratepe and Guzeyyayla $(\mathrm{Cu}, \mathrm{Mo})$ are commercial deposits. The considerable reserves of non-ferrous metals (15.9 million tons of ore with content of copper $-4.4 \%$, zinc $-6.1 \%$, gold $-0,8 \mathrm{ppm}$ and silver $-44 \mathrm{ppm}$ ) have concentrated in Chaeli deposit that the geologists call "Pontids pearl". The massive sulphide ores (VMS) form deposit with $920 \mathrm{~m}$ length (along strike); it has been traced at $650 \mathrm{~m}$ depth; its maximum capacity is $100 \mathrm{~m}$. The deposit has been overlapped by low-power layer of jasperoid quartzites (up to $2 \mathrm{~m}$ ) on deposits such as Kuroko in Japan (Matsukama, Khorikosi, 1973; Mitchel, Garson, 1984). This layer is overlapped by thickness of the interbedded tuffites and basalts covers over which green tuffs with dolomites interlayers containing foraminifera fragments lie. Turkish geologists admit that the deposit has been divided by syn-ore fault in two parts. In this regard the body is composed of two mutually overlapped "lenses". The ore body consists of massive sulphides, the most part of which has been brecciated and a small amount of non-metallic minerals - barite, dolomite, quartz, sericite and kaolinite. Sulphides have been represented by pyrite, chalcopyrite, sphalerite, and in small amounts - by galenite, bornite, tetrahedrite. Yellow (enriched by chalcopyrite) and black (enriched by sphalerite) ores have been determined within the body as well as on deposits such as Kuroko. The sphalerite content in the matrix of brecciated black ores exceeds $10 \%$. The stringer-porphyry mineralization has manifested under massive ores' deposit. Hydro-thermal-sedimentary construction which was preserved in Late Cretaceous volcanites as ore deposit was subjected to repeated brecciation under the explosive phenomena influence during hydraulic system function. Clastic ores have been preferably located in the upper parts of the deposit. Massive yellow ores and their powdered differences build-up the lower parts of the body and they are characteristic for the thickest parts of the deposit. The hyaloclastites have been extensively changed: pyritized and kaolinized. There have manifested idiomorphic pyrite emissions and matrix consists of mica and clay minerals. The felsites with rare porphyry emissions of quartz and feldspar have been distributed under hyaloclastites. The quartz-pyrite-chalcopyrite stockwork superimposed on above-mentioned rocks.

Other type of hydrothermal-sedimentary mineralization was detected in allochthon apparently displaced in paleoisland structure from marginal sea basin of Paleotethys. Rocks forming allochthon 
Genesis of Au-containing magmatic deposits of the non-ferrous metals in island-arc structures (Lesser Caucasus and East Pontids), data on inclusions and isotopic investigations

are known in reference under the name of "Cure complex"; their age is Triassic (?), they consist of ultrabasic tectonic "plates", intermittent clay shales and basalts covers represented by island arc and oceanic tholeiites as well as by rocks of depleted mantle. According to Ustaömer, Robertson (1993), geological pattern similar to Cyprus is observed in places of ore mineralization manifestation: serpentinized peridotites have been known in the lower part of section over which gabbro, dyke doleritic complex and greenstone changed pillow-lavas of basaltes have been manifested. The lavas including doleritic dykes have been overlapped by clay shales. Copper-containing massive sulphide deposits are located especially under the last ones on the pillow-lavas. It should be agreed with $\mathrm{M}$. Gyuner (1980) who added sulphurfur-pyrite deposits "refined" by copper to the Cyprus type VMS.

Epigenetic sphalerite-chalcopyrite mineralization manifested on other producing Pontids deposits. Turkish and West European geologists' works include data on composition and structure of the volcanic strata enclosing the nonferrous metals' deposits of the Eastern Pontids (Altun, 1977 and others) The basement for Late Cretaceous carriers-rocks of deposits are volcanites of andesite composition and terrigenes of Lower - Middle Jurassic age (Popovich, 2004), and as well as Upper Jurassic- Cretaceous complex with small copper and gold manifestations.

Late Cretaceous ore-bearing sediments according to (Altun, 1977) were combined into two series: the upper part was represented by basalts alternating with red limestones and "purple tuffs" (probably tuffites); lower part - dacitic tuff breccia and sandy tuffites. The deposits were formed either at the end of the dacitic strata formation or at the beginning of the volcanoes activity whereof the basic lavas flowed out (upper series). Dacite series age according to microfauna has been determined as Cenonian but according to radiometric determination data the age of large granite-granodiorite-dioritic intrusions of the region corresponds to $30 \mathrm{Ma}$ (Late Oligocene-Miocene) (Altun, 1977). According to Altun (1977) upper series basalts are blanket formations - pillow lavas. Both series volcanites have crumpled into folds, their axes have NE-SW and NW-SE trending and the first ones are more ancient.

The widespread changes of propylitization type are observed in the dacitic series rocks and sulphide stringer-porphyry mineralization - in places of quartz-sericitic metasomatites manifestation. Massive hydrothermal-sedimentary deposits have been located on dacitic tuffs (probably, on tuffites) and they are overlapped by purple tuffs. The concordant lenses of massive ores with small sizes as well as gypsum horizons have been determined at basalt series bottom. Manganese minerals have characterized for the marginal parts of the ore deposit of Chaeli deposit.

According to data Akçay, Arar (1999) the bimodal volcanites, where VMS are located, are associated with large calderas and siliceous domes. VMS were known in Murgul, Cherattepe, Kutlyuler, Kotarakdere, Khrzit and Lakhanos deposits.

The archival and published material shows that massive ores of the nonferrous metals of Pontids have formed on the seabed of deep-water basins and ore deposits have represented "ore hills" up to diagenetic transformations of sediments. The sea basins in all probability were intra-arc and their bottom was undergone rifting in Late Cretaceous, as evidenced by volcanites composition as well as basaltes dikes cutting both ore deposit and the upper basalts and purple tuffs. Rocks overlapping Chaeli ore deposit have not changed practically except for the diagenetic transformations.

It is noted Akçay, Arar (1999) that well-defined bedding is characteristic for Chaeli clastic ores; the ores consist mainly of angular and subrounded sulphides' fragments (sphalerite, pyrite and chalcopyrite). The pyrite fragments have framboidal and colloformic structures. Most probably clastic ores are formed as a result of the destruction of "sedimentary" and redeposition of the last ones on the slope and at the ore hill foot (like submarine colluvium).

The massive ores of deposit are gold-bearing: gold occurs in sphalerite as inclusions in size of $200 \mu$. Researchers can see indistinct vertical zonation (from top-downward) in the ore deposit: sphaleritegalenite-barite-chalcopyrite; pyrite-chalcopyrite-clays; pyrite-chalcopyrite-quartz. Pyrite crystals sizes are increased with depth. Clastic ores thickness increases in the southward where ore hill paleoslope has located apparently. There aren't stockworks under sedimentary ores while stringer-porphyry ones are located under the yellow ores in the north. Some of them have economic value.

It has been determined that according to chemical characteristics the ophiolite complex basalts relate to the spreading zones formation in the region of Cyure, in Ashikoy-Taykondu deposit (Çakir, 1995). It is assumed that the spreading zone has located in the back-arc basin in the Early Jurassic. 
The examples of stockwork-vein deposits reminding of copper ores of Madneuli (Georgia) are Lakhanos and Murgul connected with Late Cretaceous volcanites in Pontids. Stockwork of sphaleritepyrite-chalcopyrite composition has manifested in dacitic stock in Lakhanos. The stringer-porphyry mineralization has concentrated in the area of quartz-sericite-chlorite metasomatites development. Murgul deposit is occupied a geological position similar to the Lakhanos. Here stockwork of pyritechalcopyrite ores has been bounded from above by quartz-ferruginous (jasperoid) formations where gypsum lenses have been located on their level.

Ore-bearing lavas of dacites have been eroded and overlapped discordantly by CampanianMaastrichtian volcanites. Hydrothermal-sedimentary deposits of "black" and "yellow" ores were known in Kyzylgaya region near Murgul (Lethch Graig, 1981) for which colloform banded and framboidal textures were characterized. Here the ore-hosting rocks with an angular discordance have overlapped by andesite-dacitic lavas.

In conclusion it should be noted that gold occurrences for example Bekhsesik (Popovich, 2004) and Maradit (Lethch Graig, 1981) in the Late Cretaceous volcanites as well as in Eocene quartz diorites are known in the Eastern Pontids. The commercial value of gold occurrences has yet to be determined.

\section{BOLNISI ORE DISTRICT (GEORGIA) AND ITS ORE CONTENT}

Cretaceous volcano-tectonic depression of Bolnisi ore district was laid in the back-arc residual sea basin at the end of convergence and finally it took shape at the beginning of collision of the South Caucasus and Iran lithospheric microplates (Zonenshayn, Kovalev, 1974; Monin, Zonenshayn, 1985; Adamia et al., 2011). Depression is filled by Albian-Campanian volcanogenic-terrigenous deposits within which we have defined three complexes (Kekeliya et al., 1985, 1991, 1993). Lower precollision (Albian-Turonian) is composed of the submarine terrigenous- volcanogenic sediments with rare horizons of andesite lavas and at the base - marlaceous limestones. Volcanoes necks of fracture type being healed by diorite bodies are mapped out inside the lower complex. Magmaexcurrent structures for ground siliceous volcanites were the junctions of earlier and later sublatitudinal disturbances of NE trending. Volcanic structure subsidence was occurred after the ignimbrites and felsic acid volcanites outflowing. Ore-bearing elements are synvolcanic dome-shaped "bulges" formed in places of radiodacite extrusions squeezing-out on major volcanic edifices slopes. Extrusive domes (Madneuli), medium-size collapse caldera (David-Gareji), lava domes (Darbazi, Mushevani) are characterized for development fields of the acidic and medium-acidic effusives.

The average complex (Coniacian-Santonian) (preferably rhyodacite composition) is ore-bearing; it has been formed as a result of activation of five central type volcanoes at least in subaerial conditions and it consists of volcano-facies responding to vent-near vein zones (breccia ignimbrites, blocky tuffs, explosive breccia with ore mineralization, extrusions and lava domes) and zones of slope and foot (mainly different fragmental tuffs of dacite-rhyolite composition, tuffites, lahars, lavas of rhyolites and ignimbrites). A characteristic peculiarity of the complex is squeezed-out lava domes on the volcanoes slopes under which ore accumulations are observed.

The upper volcanic complex was formed most likely in Late Cretaceous. It is a contrast - basaltandesite-rhyolite; relics of three central type volcanoes are defined within it. The granodiorites and granodiorite-porphyries occupying the central part of the volcanic depression basement have been related to complex as comagmates. From our point of view they are "responsible" for formation of copper-gold mineralization of the region. Firstly only barite ores have been exhausted on the largest Madneuli deposit but today there are extracted copper and gold ores. From our point of view there are combined different age copper, barite-polymetallic and gold (in secondary quartzites) mineralization; on small Tsitelisopel deposit - copper and gold, on Sakdrisi deposit - gold and barite-polymetallic; on David-Garejin deposit - barite, barite-polymetallic and gold-silver. On the example of Madneuli it can be seen that ore accumulation has been preceded by metasomatic column formation stage, its upper parts are occupied by monoquartzites-solfataric formations, lower parts - by quartz-sericite metasomatites, but flanks and deep horizons - by propylites. On Madneuli two ore levels are clearly distinguished under the lava domes screen: upper level - barite and barite-polymetallic, and lower copper-sulphide. The gold-bearing quartzites "bodies" have manifested on upper and partly lower levels. 
Genesis of Au-containing magmatic deposits of the non-ferrous metals in island-arc structures (Lesser Caucasus and East Pontids), data on inclusions and isotopic investigations

It is also noted that commercial volcanogenic deposits have been located in the upper parts of the effusive sedimentary rocks' blocks of Turonian-Santonian in Bolnisi region, in the places where last ones are complicated by extrusive and lava domes. The blocks are limited by faults of NW and NE trending which are magma- and ore excurrent. On the Madneuli deposit the extrusions and lava domes have been squeezed out according to destructions' systems which form "ring" structure as a whole. Under rhyodacites lavas spreads the explosive breccias transformed into secondary quartzites, quartzhydromica metasomatites and propylites with chlorite were formed as a result of hydrothermal "collapse". It is important to emphasize that the tuffites untouched brecciation have been subjected to propylitization wherein one can be seen their primary bedding traces. On the open pit we can see (its eastern part, the horizon- $957 \mathrm{~m}$ ) tectonic contacts (the disturbances with clay gouge) of propylitized tuffites with intensely silicified and impregnated sulphides of the explosive breccia. Due to our field investigations it was confirmed that Madneuli volcano-domed structure was located on Dalidag paleovolcano slope formed besides pyroclastolites of andesite-dacites as well as by covers of ignimbrites and rhyodacites lavas. Near Madneuli it is known the following ore-bearing volcanic structures: 1) David-Gareji-barite-polymetallic caldera type where lacustrine sediments overlapped by ignimbrites are mineralized and 2) Sakdrisi gold-bearing defined by steep NE disturbance along which the effusives of rhyodacites and tuffites transformed into secondary quartzites. The commercial value of Sakdrisi deposit was proven by last year's research works (21t of gold at average gold grade 2-3ppm). Relatively poor copper stringer-porphyry ores are exhausted on Madneuli at present time.

We carried out a large volume of thermobarogeochemical investigations on Bolnisi region's deposits. According to previous research data (Arevadze, 1989; Kekeliya, 1993) two-phase gas-fluid inclusions homogenized at $320-370^{\circ} \mathrm{C}$ (maxima $-350-420^{\circ} \mathrm{C}$ ) in quartz of copper-sulphide ores; in quartz of copper-zinc ores - at $280-300^{\circ} \mathrm{C}$; in barites of barite-polymetallic ores - at $260-270^{\circ} \mathrm{C}$, and in barites of barite ores - at $120^{\circ} \mathrm{C}$ (Table 1 ).

Table1. Thermometric analysis results

\begin{tabular}{|c|c|c|c|}
\hline № & Samples numbers & $\begin{array}{l}\text { Freezing temperature of } \\
\text { gas-fluid inclusions }\end{array}$ & $\begin{array}{l}\text { Temperature of gas-fluid inclusions } \\
\text { homogenization }\end{array}$ \\
\hline 1 & Madneuli 1 & -0.9 & 320 \\
\hline 2 & “6 & -1.0 & 318 \\
\hline 3 & “ 3 & -1.3 & 325 \\
\hline 4 & “ 4 & -1.2 & 320 \\
\hline 5 & “ 5 & -1.0 & 322 \\
\hline 6 & “6 6 & -1.6 & 325 \\
\hline 7 & “ 7 & -1.2 & 320 \\
\hline 8 & “ 8 & -0.8 & 315 \\
\hline 9 & $\begin{array}{ll}6 & 9 \\
\end{array}$ & -0.9 & 318 \\
\hline 10 & “" 10 & -2.1 & 328 \\
\hline 11 & “ 11 & -1.9 & 325 \\
\hline 12 & “" 12 & -0.9 & 315 \\
\hline 13 & $\begin{array}{ll}" 13 \\
\end{array}$ & -1.2 & 320 \\
\hline 14 & “ 14 & -0.9 & 325 \\
\hline 15 & “" 15 & -0.9 & 325 \\
\hline 16 & “" 16 & -1.2 & 325 \\
\hline 17 & “ 17 & -1.0 & 315 \\
\hline 18 & “ 17 & -1.2 & 315 \\
\hline 19 & “" 18 & -1.2 & 318 \\
\hline 20 & Gadabey - Azeri 45-1 & $-1,0$ & 300 \\
\hline 21 & “" & -1.2 & 300 \\
\hline 20 & “ 3 & -0.9 & 302 \\
\hline 21 & “" 4 & -0.9 & 300 \\
\hline 22 & “ 5 & -1.1 & 305 \\
\hline 23 & 6 & -0.8 & 298 \\
\hline 24 & “ 7 & -0.8 & 295 \\
\hline 25 & “ 8 & -1.0 & 302 \\
\hline 26 & $\begin{array}{ll}6 & 9 \\
\end{array}$ & -1.2 & 305 \\
\hline 27 & “ 10 & -0.8 & 300 \\
\hline 28 & Garadag - Azeri 38-1 & $-1,5$ & 310 \\
\hline
\end{tabular}


Genesis of Au-containing magmatic deposits of the non-ferrous metals in island-arc structures (Lesser Caucasus and East Pontids), data on inclusions and isotopic investigations

\begin{tabular}{|c|c|c|c|}
\hline 29 & “" & -1.2 & 305 \\
\hline 32 & “" & -1.4 & 305 \\
\hline 33 & “" & -0.9 & 305 \\
\hline 34 & “" & -0.7 & 300 \\
\hline 35 & “" & -1.3 & 310 \\
\hline 36 & “" & -1.4 & 345 \\
\hline 37 & Kyapaz-Azeri-Kap 3 -1 & -0.7 & 300 \\
\hline 38 & 2 & -1.0 & 320 \\
\hline 39 & “" & -1.1 & 315 \\
\hline 40 & “" & -1.0 & 315 \\
\hline 41 & “" & -0.9 & 310 \\
\hline 42 & Akhtala 1 & -1.7 & 248 \\
\hline 43 & 2 & -1.6 & 245 \\
\hline 44 & “" & -1.5 & 245 \\
\hline 45 & “" & -1.7 & 245 \\
\hline 46 & “" & -1.6 & 246 \\
\hline 47 & “" & -1.9 & 248 \\
\hline 48 & “" & -1.8 & 248 \\
\hline 49 & “" & -1.7 & 250 \\
\hline 50 & “" & -1.7 & 245 \\
\hline 51 & $\begin{array}{ll}\text { “ } & 10 \\
\end{array}$ & -1.6 & 245 \\
\hline 52 & “ 11 & -1.6 & 246 \\
\hline 53 & “ 12 & -1.5 & 246 \\
\hline 54 & Tekhut 1 & -1.0 & 330 \\
\hline 55 & “" & -0.6 & 325 \\
\hline 56 & “" & -0.8 & 328 \\
\hline 57 & “" & -0.7 & 320 \\
\hline 58 & “" & -0.5 & 320 \\
\hline 59 & 6 & -0.8 & 325 \\
\hline 60 & “" & -1.0 & 330 \\
\hline 61 & "6 & -1.3 & 330 \\
\hline
\end{tabular}

According to cryometric investigations of fluid inclusions the salinity of solutions that deposited copper and polymetallic ores, was low and equal to $\sim 40$ gram equivalent of $\mathrm{NaCl}$ per liter of solution. The solutions were chloride-sulphate, potassium-sodium and contained nitrogen and $\mathrm{CO}_{2}$. There were also determined heavy hydrocarbons and methane, their total concentration didn't exceed 4 mol.\%.

Data on isotopic composition of sulfur are the following: $\delta^{34} \mathrm{~S}$ values are slightly deviated from meteoritic standard in sulphates; $\delta^{34} \mathrm{~S}$ values range from +10 to $+20 \%$ in most sulphates (Table 2 ). Data on isotopes of carbon, hydrogen and oxygen are varied and can be interpreted in favor of the participation of both meteoric and magmatogene water in ore formation process. So, the values of $\delta^{13} \mathrm{C}$ are grouped around values of $-7,1 \pm 2,1 \%$ and $+0,3 \pm 1,6 \%$ in calcite and fluid inclusions; the isotopic composition of fluids hydrogen $(\delta \mathrm{D}$ water) varies within $-70-90 \%$, and recent region water from -50 to $-70 \% ; \delta^{18} \mathrm{O}$ ranges from +10.35 to $+9,25 \%$ (Table 3 ) in quartz of copper ores and it ranges from -1.07 to $-1,53 \%$ in barite of barite-polymetallic ores.

Table2. Sulphur isotopes ratio in sulphides

\begin{tabular}{|c|c|c|}
\hline № & Deposits, № samples, minerals & $\delta^{34} \mathrm{~S}, \% \mathbf{0}$ \\
\hline 1 & Madneuli, 9, pyrite & 3.3 \\
\hline 2 & Madneuli, 9, pyrite & 3.6 \\
\hline 3 & Madneuli 32, pyrite & -1.2 \\
\hline 4 & Madneuli 32, pyrite & -1.3 \\
\hline 5 & Madneuli, 33, chalcopyrite & -1.4 \\
\hline 6 & Madneuli, 35, chalcopyrite & 2.5 \\
\hline 7 & Madneuli, 40, pyrite & 2.2 \\
\hline 8 & Madneuli, 40, pyrite & 3.3 \\
\hline 9 & Madneuli, 41, pyrite & 2.7 \\
\hline 10 & Gadabey, Az KS 3 PY, pyrite & 1,5 \\
\hline 11 & Gadabey, Az 51 PY, chalcopyrite & 2,6 \\
\hline
\end{tabular}


Genesis of Au-containing magmatic deposits of the non-ferrous metals in island-arc structures (Lesser Caucasus and East Pontids), data on inclusions and isotopic investigations

\begin{tabular}{|c|c|c|}
\hline \hline 12 & Garadag, Az 1008a PY, pyrite & 2,0 \\
\hline 13 & Bitti-Bulag, Az A 12 2PY, pyrite & $-2,3$ \\
\hline 14 & Bitti-Bulag, Az A 12 enargite & $-4,0$ \\
\hline 15 & Gadabey, Az E 413, sphalerite & 4,2 \\
\hline 16 & Novogorelovka, AzF 431, sphalerite & 4,8 \\
\hline 17 & Gyulyatag, Az 63 1PY, pyrite & $-1,4$ \\
\hline 18 & Damirli, Az62 1 PY, pyrite & $-1,0$ \\
\hline 19 & Paragachay, Az 85 3PY, pyrite & 0,9 \\
\hline 20 & Gadabey, Az 731 PY, pyrite & 1,2 \\
\hline 21 & Garadag, Az 1008b PY, chalcopyrite & 2,5 \\
\hline 22 & Gadabey, BMFR 1, sphalerite & 7,2 \\
\hline 23 & Alaverdi, 1, chalcopyrite & 2.6 \\
\hline 24 & Shamlug, 2, chalcopyrite & 0.9 \\
\hline 25 & Shamlug, 3, chalcopyrite & 0.3 \\
\hline 26 & Tekhut, 9, chalcopyrite & 1.4 \\
\hline
\end{tabular}

Table3. Oxygen isotopes ratio in ores quartz

\begin{tabular}{|c|c|c|}
\hline$№$ & Samples description & $\delta^{18} \mathrm{O}, \% 0$ \\
\hline 1 & Madneuli- 32, pyrite-chalcopyrite ores & 9.1 \\
\hline 2 & Madneuli- 33, pyrite-chalcopyrite ores & 8.1 \\
\hline 3 & Madneuli- 34, pyrite-chalcopyrite ores & 9.0 \\
\hline 4 & Madneuli- 35, pyrite-chalcopyrite ores & 9.2 \\
\hline 5 & Madneuli- 33, pyrite-chalcopyrite ores & 11.4 \\
\hline 6 & Garadag - Azer 1008-v, copper-porphyry ores & 10,2 \\
\hline 7 & Garadag - Azer 1008-B, copper-porphyry ores & 11,3 \\
\hline 8 & Garadag - Azer 1008-e, copper-porphyry ores & 11,1 \\
\hline 9 & Bitti-Bulag, Azer A13-3, pyrite-enargite ores & 9,4 \\
\hline 10 & Damirli - Azer 62-2, copper-porphyry ores & 12,8 \\
\hline 11 & Paragachay, Azer 53-3, copper-molybdenum ores & 9,7 \\
\hline 12 & Gyulyatag - Azer 63-3, pyrite-chalcopyrite ores & 12,8 \\
\hline 13 & Janyatag - Azer 611, pyrite-chalcopyrite ores & 6,9 \\
\hline 14 & Gadabey - Azer Vb-1-pyrite-chalcopyrite ores & 8,9 \\
\hline 15 & Tekhut-9, copper-porphyry ores & 10.05 \\
\hline
\end{tabular}

The authors have data on the isotopic composition of strontium and concentrations of rubidium and strontium in rocks located near the volcanogenic deposits. It emerged that the basalts of Bolnisi region $\left({ }^{87} \mathrm{Sr} /{ }^{86} \mathrm{Sr}=0,704910\right)$ could be products of the undepleted mantle differentiation but the rhyodacites could arise in the lower parts of crust on Murgul deposit (Turkey) $\left({ }^{87} \mathrm{Sr} /{ }^{86} \mathrm{Sr}=0,707739\right)$; rhyolites of Madneuli deposit - in the lower parts of the upper crust $\left({ }^{87} \mathrm{Sr} /{ }^{86} \mathrm{Sr}=0,710269\right)$. Europium ratios (for rhyolites $\mathrm{Eu} / \mathrm{Eu}^{*}=0.65-0.68$, ignimbrites $\left.-0.52-0.58\right)$ determined in them, as well as rocks enrichment by light REE and large ionic lithophylic elements indicate crustal source of rhyolites and ignimbrites magmas (Gugushvili et al., 2002). Higher $\mathrm{Zr} / \mathrm{Y}$ ratios in these rocks indicate that (for dacites, - 9.5-11.2; for rhyolites - 2.7; for basalts - 3.7-4.1) probably we have dealing with more mature paleoarc (Baba-zadeh, et al., 2012).

\section{GADABEY ORE DISTRICT (AZERBAIJAN) AND ITS ORE CONTENT}

Gadabey ore district as one of the largest regions in the Caucasus with a long history of gold-copperproducing industry, with its gold-copper-sulphide and gold-copper-porphyry mineralization is the most typical for the development of Upper Bajocian volcanogenic complexes (Baba-zadeh, 1990; Baba-zadeh, et al., 2012; Baba-zadeh, Abdullayeva, 2012).

It is located in the axial line of large Shamkir horst-uplift complicated by the Upper Jurassic-Lower Cretaceous Ajikend- Dashkesan superimposed trough. Its disjunctive framework consists of two systems of faults: early, northwest and later, the north-east. Main Gadabey fault zone tracing in the south-west region belongs to the first of them.

A special place in the ore district structure is given to its central part where well-known Gadabey gold-copper-sulphide ore field controlled by volcano-dome structure and complicated by radial faults. There are located Bitti-Bulag, Ertepe (Novo- Gorelovskoe), Maskhit and other deposits and ore manifestations of gold-copper-sulphide, gold-copper-arsenic, gold-copper-polymetallic ores representing Gadabey ore-magmatic system in total. 
The ore bodies have been confined to the upper strata horizons of rhyolites and rhyodacites; they have turned generally into secondary quartzites. Ore bodies' part has concentrated in main volcanites of Early Bajocian. These strata were intruded by dikes connected with the establishing andesite-basaltplagiorhyolitic and basalt-andesite-dacite-rhyolitic formations and also by comagmated with them Mesozoic plagiogranites (Atabek-Slavyan intrusion) and gabbro-diorites, quartz-diorites and etc. (Gadabey intrusion). They can be joined in a volcano-plutonic association according to all features complex.

The main ore bodies of Gadabey deposit (Karl-stock, Fedorov-stock) have been confined to the most uplifted blocks parts at the intersection node of half-ring fault with submeridional disturbance stretching along the central part of the deposit. In the post-ore stage during renewed tectonic motions the formed deposit blocks were removed with respect to each other and there were thrown down a part of Fedorov-stock.

General morphology and structural peculiarities of the Garadag ore field as the central part of Gadabey ore district determine Maarif-Garadag ore-controlling (boundary) fault of northwest (submeridional) trending and also the diagonal ore supplying faults to which crushing and shearing zones, small zones of eruptive breccias, subvolcanic and hydrothermal formations have been confined. Zones of increased fracturing, adjacent to these faults were place of Late Jurassic (Early Cretaceous?) stork-works of gold-bearing Cu-Mo porphyry mineralization. Due to dynamic stresses the space between the ore-controlling faults represents highly-fractured block where the fractures are located perpendicular to ore-supplying (Garadag) fault. Their direction is sublatitudinal or northeast. These fractures network contains subvolcanic dikes suites of quartz-diorite porphyrites and veinletvein mineralized zones.

Maarif and Maskhit ore fields with analogous deposits of Garadag mineralization group are determined within Maarif-Garadag ore-controlling fault. The development of copper-porphyry ores is also assumed at deep horizons of copper-arsenic deposit of Bitti-Bulag.

Gadabey deposit was formed at temperatures of $295-305^{\circ} \mathrm{C}$ according to the temperature data of gasfluid inclusions homogenization (Table. 1).

\section{ALAVERDi ORE DISTRICT (ARMENIA) AND ITS ORE CONTENT}

In Alaverdi region the copper-containing stock-like ore bodies concentrated in Late Bajocian horizons of aleurolites and sandstones but the vertical vein-like - in rhyodacite hyaloclastites and effusives of andesite-basalts of Early Bajocian age. The vein bodies were marked by narrow bands of quartzsericite-chlorite metasomatites. Moreover the article's authors have investigated Tekhut copperporphyry deposit located near Alaverdi that is situated in Shnokh-Kokhb tonalite intrusion of Early Cretaceous age.

According to K-Ar method data, phaneric intrusions' age is Neocomian ( $133 \pm 8 \mathrm{Myr} /$ million years). "Background" (phaneric) igneous rocks as well as porphyry bodies are appreciably sodium and highaluminous and relate to tonalites group (Kekeliya et al., 1985).

According to the data of Yaroshevich (1985), who investigated the gas-fluid inclusions and fluids whereof ore material falling out occurred, they were chloride-sodium-potassium highly concentrated $\left(50-20 \mathrm{wt} \%\right.$ or $30-40 \mathrm{~g} / \mathrm{kg}$ on $\mathrm{NaCl}$ base); mineral formation occurred in the interval of $400-220^{\circ} \mathrm{C}$, the pressure could exceed 100kbar; sulphide sulfur was characterized by low dispersion of $\delta^{34} \mathrm{~S}$ values on Tekhut deposit and approached to meteoric standard; sulfate sulfur weighted at 13,5\% (anhydrite) with respect to the sulphide. Oxygen isotopic composition of water inclusions ranges from +3.0 to $4.1 \%$ that can indicate magmatic water dilution (fluids) by meteoric ones.

Alaverdi ore district covering the extreme south-western part of the Lok-Garabag tectonic zone paleoisland-arc structure fragment is mainly composed of Bajocian-Bathonian and Late Jurassic-Early Cretaceous volcanic complexes in its central part.

Alaverdi volcanic structure was formed at least as a result of three powerful phases of volcanic activity. The fracture-type volcanoes functioned and lavas of andesite-basalts and in lesser degree basalts flowed out on the surface at the beginning (Early Bajocian). In our opinion these formations are pre-subducted, formed during divergence of the South Caucasus and North Iran lithosphere 
microplates. There were formed two volcanic depressions filled with lavas of andesite-dacites, their breccias and pyroclastolites on the wide lava fields of previous out-flows as well as filled with rhyodacites, their pyroclastolites and hyaloclastites at later phase of the central type volcanoes activation in Late Bajocian. Akhpat plagiogranite and Akhtal granodiorite-porphyry intrusions exposed in the most eroded parts of the volcanic necks. The latest phase of the Middle Jurassic volcanism manifested apparently in Bathonian. For example vent and near vent facies of local volcano represented by blocky and agglomerate breccias of andesite-basalts are mapped in the western part of Alaverdi ore field. These facies eroded intensively while volcano grew. This led to the shelves' formation of stratified Colluvium on its eastern slope.

According to common geological data there are four groups of endogenous deposits of non-ferrous metals in the region. It is assumed that barite-polymetallic ores confined to the apical part of Akhtal intrusion are the earliest ones. Alaverdi copper deposit was formed apparently in Late BajocianBathonian but Shamlug - in Late Jurassic as massive copper-sulphide stocks were screened by Late Jurassic rhyodacites here. The above-mentioned copper-porphyry Tekhut deposit showing paragenous connection with the Early Cretaceous tholeitic complex is the youngest mineralization of subduction stage of paleoisland-arc structure development. Due to available data (temperature of gas-fluid inclusions homogenization in ores quartz (Averadze, 1989, Kekeliya et al., 1993) Alaverdi deposit was formed at temperatures of $205-280^{\circ} \mathrm{C}$, Shamlug - at $185-210^{\circ} \mathrm{C}$ and Akhtal - at $170-200^{\circ} \mathrm{C}$. There were determined $\mathrm{N}_{2}, \mathrm{CO}_{2}$ and a small amount of water taken from gases in inclusions. The high concentrations of $\mathrm{SO}_{4}{ }^{2-}, \mathrm{Ca}, \mathrm{Na}$ have been determined in water extracts from the gas-fluid ores inclusions of Gafan deposit that is an analogue of Alaverdi. Moreover the considerable concentrations of heavy metals together with ordinary cations $(\mathrm{K}, \mathrm{Na}, \mathrm{Ca}, \mathrm{Mg})$ were revealed in water extracts. The isotopic composition of sulphides sulfur is practically similar to meteoritic sulfur composition in deposits of Gadabey and Alaverdi regions. Pyrites of early quartz-pyrite stage of mineral formation are characterized by $\delta^{34} \mathrm{~S}=4.9 \%$ value but at chalcopyrite-pyrite-sphalerite stage $-1.2-1.5 \%$ that can be explained by sulphides sulfur lightening due to ${ }^{34} \mathrm{~S}$ accumulation in barite and anhydrite. The isotopic composition of chalcopyrite sulfur $-2.6 \%$ and sphalerite -4.2 and $7.2 \%$ shows stage ore formation of Gadabey deposit (Table 3). The isotopic composition of oxygen in quartz taken from copper deposits of Gadabey ore district was equal: $+8,9-11,3 \%$, Mekhman ore district (Azerbaijan) +6,9 - 12,8\%o, Paragachay copper-molybdenum deposit (Daralagez block, Azerbaijan) - + 9,7\%, Alaverdi ore district $+10,3 \pm 0,5 \%$ (Table 3). Water hydrogen from fluid inclusions (Alaverdi deposit) is characterized by $\delta \mathrm{D}$ values being equal to $-75 \pm 0,5 \%$. To this must be added the new data on isotope ratios of sulphides sulfur and oxygen taken from quartz on Bolnisi, Gadabey and Alaverdi regions deposits (see. Table. 2 and 3). The analyses were carried out in USGS laboratory (Denver, USA). The temperatures of gas-fluid inclusions homogenization in quartz taken from epigenetic deposits of the Lesser Caucasus were determined in this laboratory. The temperatures of fluid inclusions homogenization taken from copper ores on Madneuli were equal to $315-325^{\circ} \mathrm{C}$, on Gadabey gold-copper-sulphide deposit - to $295-305^{\circ} \mathrm{C}$, on Kyapaz gold-sulphide deposit - to 300$320^{\circ} \mathrm{C}$, on Akhtala polysulphide deposit - to $245-250^{\circ} \mathrm{C}$, on Tekhut copper-porphyry deposit - to 325$330^{\circ} \mathrm{C}$, on Garadag - to $340-345^{\circ} \mathrm{C}$, (Table. 2).

Isotopic ratios of oxygen taken from copper and copper-molybdenum ores' quartz on Madneuli, Gadabey, Bitti-Bulag, Gyulyatag, Janyatag, Damirli, Garadag, Paragachay and Tekhut deposits (Table. 3) can testify in favor of the magmatogenic water participation in ore formation process (Taylor, 1982). The ratios of sulfur isotopes taken from sulphides are various on epigenetic deposits of Lesser Caucasus island paleoarc. This work authors consider that a big part of sulfur had a magmatogenic source.

\section{CONCLuSion}

From the above-mentioned one can be inferred that the ore deposits of paleoisland-arc structures in particularly the Pontic-Lesser Caucasus arc it should to be expected in the following geological conditions: in the craters and on paleovolcanoes' slopes located in volcanic depressions; ore bodies in the siliceous parts of volcanogenic-sedimentary strata or above them (in the case of hydrothermalsedimentary deposits); generally the ores are overlapped by main volcanites but there may be exceptions - for example Madneuli deposit; we often observe gypsum accumulations on the flanks of 
ore bodies and in their hanging wall; mineral composition is practically identical on all copper deposits. Madneuli deposit of Georgia is an exception where different stage gold, barite-sulphide and copper ores spatially bring together in one volcano-structure. Pay attention to the ore-bearing strata composition: a) Thin chemogenic-sedimentary deposits are changed from top to bottom by hyaloclastites, accumulations of underwater Colluvium, tephritic turbidites, lavas of dacites and andesites in Gadabey and Alaverdi ore districts in the section of Middle Jurassic stratum; ore-bearing stratum is overlapped by Late Jurassic complex representing alternation of andesite-basalt sheets with different fragmental carbonate-containing tuffites; b) in the Bolnisi region - ore-bearing stratified sediments (tuffites with rare dacites sheets or crater-lacustrine sediments) overthrusted by ignimbrites (ground formations) and rhyodacites lavas; c) Chaeli volcanic structure that includes hydrothermalsedimentary ores is composed of supra-ore basalts (pillow-lavas) alternating with limestones and "purple" tuffs as well as with propylitized dacites. Massive sulphide ores occur on the last ones under which the stringer-porphyry copper ores have been manifested in quartz-chlorite-hydromicaceous metasomatites. Volcanic structure represents a large caldera that has located at the bottom of the deep water basin.

The ores of Lesser Caucasus deposits are clearly epigenetic: stringer-porphyry and vein mineralization has been superimposed on hyaloclastites and tuffites in Gadabey and Alaverdi ore districts; the stringer-porphyry copper mineralization has been manifested in silicified tuffites in Bolnisi as well as the disseminated gold and barite-sulphide mineralization as veins and flat deposits - in secondary quartzites. The Chaeli deposits' ores are similar to "ore hills" of modern mid-ocean ridges and rifting zones of the marginal seas.

The ore bodies have been located in cover of narrow bands of quartz-serite-chlorite metasomatites in Gadabey and Alaverdi ore districts; vertical metasomatic column has manifested in Bolnisi region: at the upper part - secondary quartzites (subsurface solfataric changes), and at the lower part - highertemperature silicification (quartz-chlorite-sulphide metasomatites with small quantity of sericite). Ore metasomatites have been surrounded by propylites cover. On Chaeli (Madenkoy) type deposits under hydrothermal-sedimentary deposits the stringer-porphyry "yellow" ores have been surrounded by quartz-hydromica metasomatites in dacites underlying them against the background of regional propylites. The last ones mark the advance ways of hydrothermal solutions to the sea paleo-floor.

The stocks and narrow veins-lenses (northern lenses group in Gadabey) of copper ores have revealed in Gadabey and Alaverdi ore districts; the high-volume copper stockworks have preferably manifested in Bolnisi region; thick deposits of lenticular massive sulphide ores consisting mainly of pyrite, chalcopyrite and sphalerite together with stockworks have revealed in Eastern Pontids.

In our opinion, these differences have been determined by different geodynamic regimes of individual crustal blocks of paleoisland-arc structures.

Thermobarogeochemical investigations have shown that the main copper and gold deposits as one of the major associate ores components were formed in the similar RFF (Reserve Fuel Facility) conditions despite the difference in ore deposition mechanism and therefore they refer to single genetic volcanogenic deposits class.

\section{REFERENCES}

[1] Adamia Sh., Zakariadze G., Chkhotua T., Sadradze N., Tsereteli N., Chabukiani A., Gventsadze A. (2011). Geology of the Caucasus: A Review. Turkish Journal of Earth Sciences 20: 489-544.

[2] Akçay M., Arar M. (1999). Geology, mineralogy and geochemistry of the Çayeli massive sulphide ore deposit, Rize, NE Turkey. In: A. Stanley, editor, Mineral Deposits: Processes to processing, Balkema, Rotterdam, pp.459-462.

[3] Altun Y. (1977). Geology of the Çayeli-Madenköy copper-zinc deposit and the problems related to mineralization. Ankara, Mineral Research and Exploration Bulletin 89: 10-24.

[4] Arevadze V.A. (1989). Physical-chemical conditions of endogenous deposits formation of Transcaucasus. Abstract. Sc.D. thesis. geol.-min. as scientific paper. Institute of Geology, Tbilisi, Georgia (in Russian).

[5] Baba-zadeh V.M, Abdullayeva Sh.F., Kekeliya S.A., Kekeliya M.A. (2012). Gold-bearing volcanogenic deposits of nonferrous metals of Lesser Caucasus and Eastern Pontids and their genesis. News of Baku University. Natural Sciences Series 1: 55-96 (in Russian). 
Genesis of Au-containing magmatic deposits of the non-ferrous metals in island-arc structures (Lesser Caucasus and East Pontids), data on inclusions and isotopic investigations

[6] Baba-zadeh V.M. (1999). Sulphide metallogeny and evolution Meso-Cenozoic volcanism of the Lesser Caucasus. News of Baku University. Natural Sciences Series 4: 113-132 (in Russian).

[7] Baba-zadeh V.M., Abdullayeva Sh.F. (2012). Precious metal ore-magmatic systems. Baku: Baku State University (in Russian).

[8] Baba-zadeh V.M., Makhmudov A.I., Ramazanov V.G. (1990). Copper and molybdenum porphyry deposits. Baku: Azerneshr (in Russian).

[9] Çakir Ü. (1995). Geological characteristics of the Aşiköy-Toykondu (Küre-Kastamonu) massive sulphide deposits. Mineral Research and Exploration Bulletin 117: 29-40.

[10] Dixon C.J., Pereira J. (1974). Plate Tectonics and Mineralization in the Tethyan Region. Mineralium Deposita 9: 185-198.

[11] Gugushvili V.I, Kekeliya M.A., Mun Ch., Natsvlishvili M.P. (2002). Crustal and mantle sources of Cretaceous volcanism and sulphide ore formation in Bolnisi ore district. Proceedings of GIS of AS Georgia, New Series, 117: 412-419.

[12] Güner M. (1980). Sulphide ores and geology of the Küre area Pontid in N Turkey. Mineral Research and Exploration Bulletin: 65-109.

[13] Kekeliya S.A., Ambokadze A.N., Ratman I.P. (1993). Volcanogenic deposits of nonferrous metals of paleoisland-arc structures and their prediction methodology. Tbilisi: Metsniereba, p.96 (in Russian).

[14] Kekeliya S.A., Chichinadze L.L., Starostin V.I. (1985). Geological and structural peculiarities of copperporphyry mineralization localization in pyrite-bearing province. Geology of ore deposits 1: $71-79$ (in Russian).

[15] Kekeliya S.A., Yaroshevich V.Z., Ratman I.P. (1991). Geological and genetic models of alpine volcanogenic deposits of nonferrous metals of Mediterranean metallogenic belt. Geology and Geophysics 8: 71-79 (in Russian).

[16] Lethch Graig H.B. (1981). Mineralogy and textures of the Lakhanos and Kizilkaya massive sulphide deposits, Northeastern Turkey, and their similarity to Kuroko ores. Mineral deposita 16 :241-257.

[17] Matsukama T., Khorikosi E. (1973). Review of Kuroko deposits in Japan. T.Tatsumi, editor. Volcanism and ore formation. M.: Mir, pp.129-151.

[18] Mitchel A., Garson M. (1984). Global tectonic position of mineral deposits. M.: Mir.

[19] Monin A.S., Zonenshayn L.P., editor. (1987). The history of Tethys Ocean. M.: Institute of Oceanology.

[20] Okay A.I., Şahintürk O. (1997). Geology of the Eastern Pontides. In: Robinson A.G., editors. Regional and petroleum geology of the Black Sea and surrounding region. American Association Petroleum Geologists Memoir 68: 291-311.

[21] Popovich R. (2004). Auriferous mineralization in the Murgul-Artvin-Maradit area (Northeastern Turkey). Mineral Research and Exploration Bulletin 129: 17-29.

[22] Taylor Kh.A. (1982). Isotopes of oxygen and hydrogen in hydrothermal ore deposits. Kh.L. Barns, editor. Geochemistry of hydrothermal ores deposits. M.: Mir: 200-237.

[23] Ustaömer T., Robertson A.H.F. (1993). Late Paleozoic-Early Mesozoic marginal basins along the active southern continental margin of Eurasia: evidence from the Central Pontides (Turkey) and adjacent regions. Geological Journal 120: 1-20.

[24] Yaroshevich V.Z. (1985). Deposits genetic peculiarities of main ore formations of Caucasus according to isotopic research data. Ph.D. Institute of Geology, Tbilisi, Georgia.

[25] Yilmaz A., Adamia Sh., Chabukiani A., Chkhotua T., Erdogan K., Tuzcu S., Karabiyikoğlu M. (2000). Structural correlation of the Southern Transcaucasus (Georgia) - Eastern Pontides (Turkey). In: Bozkurt E., Winchester L.A., Piper J.D.A, editors. Tectonics and Magmatism in Turkey and the Surrounding Area. Geological Society Special Publication, 173, 17, London: pp.185-198.

[26] Yilmaz Y., Tüysüz O., Yigitbash E., Genç S., Şengör A.M.C. (1997). Geology and tectonic evolution of the Pontides. In: Robinson A.C., editors. Regional and petroleum geology of the Black Sea and surrounding region. American Association Petroleum Geologists Memoir, 68, pp.183-226.

[27] Zonenshayn A.P., Kovalev A.A., editors. (1974). New global tectonics (plate tectonics). M.: Mir (in Russian). 


\section{AUTHORS' BIOGRAPHY}

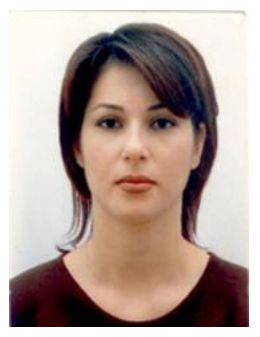

Assosiate prof. Shahla Abdullayeva for the first time, a comparative analysis of formation patterns of the noble-metal ore-magmatic systems on the Lesser Caucasus within the western segment of the Somkhit-Garabag island arc is carried out.

Noble-metal ore-magmatic systems are polygenic by their nature and are controlled by volcanic-domic and site-depression structures of various types.

Noble-metal deposits are divided on particularly gold-ore with silver (Chovdar, Goygol), mostly gold-containing with silver (Daghkesaman, Kedabek, Gosha and others), mostly gold- and silver-containing (Garadag, Kharkhar and others), mostly silver-containing with poor gold-bearingness (Danayeri, Bashkishlag and others) volcanogenic hydro-thermal types.

There are selected geological-industrial types of gold-ore and gold-containing deposits. They are related to medium and large complex-structured mineralization vein zones, and also gold-secondaryquartizic since the discovery of the Chovdar deposit.

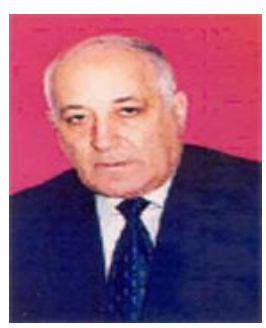

Academician Vasif Baba-zadeh, for the first time developed metallogeny of the Earth ophiolitic belts, defined extension mercury belt of the Lesser Caucasus and lineament zones of long endogenic activity and ring structures in South Caucasus, compiled "Spacetectonic map of Azerbaijan" (1:600 000) and "Map of regional jointing with prediction of economic minerals of Azerbaijan" (1:600 000), used formational analysis of some segments of the Mediterranean metallogenic belt, developed geological-genetic models of ore-magmatic systems, gave prediction assessment and perspectivity of industrial using of gold-ore, copper and molibden fields, suggested theoretical preconditions of discovering ore fields of black, non-ferrous and noble metals in different structural-formational zones of Azerbaijan; as an expert was in research projects "For official using", has CRDF grant (USA 2005-2007) and 6th Council of Europe frame Programme (INTAS) (2007-2009), took part in preparations to laws: "About interior part" (1998) and "About Education" (2008).

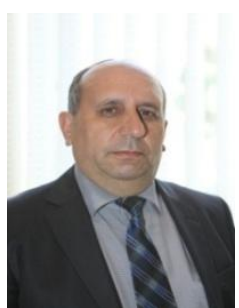

Professor Nazim Imamverdiyev, is a renowned expert in the field of petrology and geochemistry of igneous rocks. They first studied at the present level petrology and geochemistry of Late Cenozoic volcanic formations of the Lesser Caucasus. Based on detailed petrological-geochemical, mineralogical studies first defined physicochemical conditions of crystallization Late volcanic formations of the Lesser Caucasus, revealed the composition of the parental magma, estimated melting of the mantle source and the role of mantle metasomatism in the formation of these magmas. He hase proved that Late Cenozoic volcanic formations formed in the Lesser Caucasus collision-rifting conditions.

N. A. Imamverdiyev based on petrogeochemical data noticed that the Neogene-Quaternary volcanics of the Lesser Caucasus formed at different degrees of melting of subduction- enriched subcontinental lithospheric mantle. Prints of subduction decreased during the evolution of these volcanic formations over time due to increasing the share of the asthenosphere part of the Neogene-Quaternary time. It inherited subduction imprint in the Neogene-Quaternary volcanic rocks indicates the existence of mantle lithosphere beneath the modern Turkish-Iranian plateau, including the Lesser Caucasus. Partial melting of the rising asthenosphere in the Arabian-Eurasian collision zone contributed to the enrichment of large alkali content for younger volcanics magma that caused regional delamination (peeling) of the lithospheric mantle.

Professor Sergo Kekeliya, Geology Institute of Georgia, the department of Geology. Known specialist on Caucasus. Main interests are: geology, metallogeny, tectonics, igneous petrology and geochemistry.

Ph.D. Maren Kekeliya, Geology Institute of Georgia Associate professor, the department of Geology, Specialist on Caucasus. Main interests are: geology, metallogeny, geochemistry and petrology. 
Genesis of Au-containing magmatic deposits of the non-ferrous metals in island-arc structures (Lesser Caucasus and East Pontids), data on inclusions and isotopic investigations

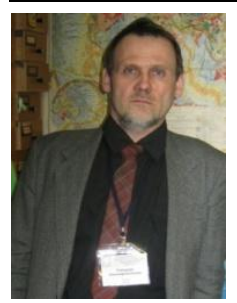

Ph.D. (geol. miner.) Alexander Romanko, is a specialist in geology, tectonics, igneous petrology and geochemistry; also, he has studied some problems of metallogeny, oil and gas - hydrocarbons (HC) etc. Ph.D on Proterozoic igneous rocks in Pechenga (Petsamo) zone, Kola Peninsula. Worked in Precambrian Fennoscandian (Baltic) Shield, E. Iran and Caucasus, Tien-Shan, Pamir (Pamirs), Urals, Kamchatka, some structures of Tajikistan etc. Member of the IAVCEI (International Association of Volcanology and Chemistry of the Earth's Interior). Author and co-author of more than 310 different scientific publications.

Citation: Shahla Abdullayeva et al. (2017). Genesis of Au-containing magmatic deposits of the non-ferrous metals in island-arc structures (Lesser Caucasus and East Pontids), data on inclusions and isotopic investigations, International Journal of Mining Science (IJMS), 3(2), pp.26-39, DOI: http://dx.doi.org/ 10.20431/2454-9460.0302003.

Copyright: (C) 2017 Alexander Romanko. This is an open-access article distributed under the terms of the Creative Commons Attribution License, which permits unrestricted use, distribution, and reproduction in any medium, provided the original author and source are credited 